\title{
'Doll Made of Unused Goods' Decreases the Children's Anxiety in Disaster Areas
}

\author{
Lilis Madyawati, Hamron Zubadi, Dede Yudi \\ Muhammadiyah University of Magelang, Tidar Street 21, Magelang, Indonesia \\ Corresponding e-mail: lilis_madya@yahoo.co.id
}

\begin{abstract}
Disaster is a cause of stress for children, especially when they face the disaster directly by themselves. Anxiety in this research is a feeling experienced by children in disaster areas due to the disaster. It usually appears in behavioral psychological disorder. 'Brangkas (doll made of unused goods)' is a therapy given to the children through playing game. Children may able to express their frustration, hostility, and anger when they play the game using doll made of unused goods'. The research aims to know the influence of this media toward the children's anxiety. The research design uses one group pre-posttest design with 30 subjects. The data collecting method uses questionnaire. The data is analyzed using Wilcoxon test. The result shows that 26 subjects (87\%) have nightmares, 21 subjects (71\%) show excessive attachment, 16 subjects $(52 \%)$ are easily angered, and 17 subjects $(55 \%)$ have aggressive behavior. After the children are treated by using this play therapy media, 27 subjects show decreased anxiety. Based on statistic test, there is influence of 'Brangkas (doll made of unused goods)' toward children's anxiety. The doll made of unused goods can decrease the children's anxiety in disaster areas.
\end{abstract}

Keywords: doll made of unused goods, children in disaster areas

\section{INTRODUCTION}

Children's world is playing world. For children, playing will develop their skills, such as motor skill that enable them to move fast, run, and do any kind of activities. Disaster is a cause of stress for children, especially when the disaster happens in their surroundings. The condition during and post disaster may make the children lost their control. Depressed children usually show cranky, badtempered, aggressive, coward, suspicious, and sensitive attitude (Hurlock, 1999). Anxiety is the main effect of disaster for children. The anxiety can be shown by biting fingers/thumb, nightmare, and excessive attachment. The response of children's anxiety depends on the children's age. According to Wright (2005), who examines the playing therapy on children, the common children's responses on disaster are sad, afraid, and guilty feeling since they face something they never experienced before. They also will feel insecure, discomfort, miss some parts of their previous life and also feel sudden uncertain feeling. According to a research done by Coyne
(2008), children in disaster areas often feel anxious and worried because the face and see the disaster by themselves or because they stay in new environment just like shelter or refuge. Anxiety due to disaster, which is also supported by the research by Folley (2010), illustrates that parents should adapt themselves on their role as a parents with stressful children cause of disaster. After the disaster, children face various kinds of symptoms such as face flashback, avoid any kind or trauma reminders, become irresponsive, diminish their interest to the pervious interesting things, feel have no future, increase the sleep disorder, feel irritable, have lack concentration, and easy to get shocked (National Institute of mental Health, 2008 Other symptoms include the act of crying, screaming, moaning, immobility, being confused, hyperactive, being introvert (Kalayjian, 2004), darkness phobia (Lystad, 2005), appetite disorder, aggressiveness, and separation anxiety (Speier, 2005). One of mental approach in order to reduce anxiety is playing. Playing becomes the appropriate intervention for children after the disaster. The goal (of playing) is 
supporting the children to participate in their social life, get their get their responsibility, control their emotion, show respect to others, have selfacceptance and acceptance of others, increase social skill and self-esteem, and to reduce the depression as well. Playing can reduce separation anxiety syndrome on children (Shoaakazemi et.al. 2014).

Play therapy using interesting media is one of the therapy means for children. Therapeutic value in play therapy media is very good for mental health since it helps the children to communicate their feeling effectively and naturally, train their selfcontrol and concentration, and decrease the anxiety. One of interesting play therapy media is 'Brangkas (doll made of unused goods). This doll (made of unused goods) can evoke the children's spirit of life that formerly decreases because of conflict, and disaster. It also decreases the depression. Through the game using this media, the children also get pleasure that make them become more cooperative to instructors and therapists during the therapy session. The instructors and therapists should attempt to obtain the children's growth runs optimally during the therapy session, despite the attempt to decrease the children's anxiety. The writers intend to do research on doll made of unused goods to decrease the children's anxiety in disaster areas. The doll made of unused goods is the media used by the researcher to solve the anxiety problem on children. Play therapy can be done using many kinds of media and using many ways. the use of this doll made of unused goods is because this media is representative media, easy to get the tools and materials, safe to use, pleasant in its applying, and attractive and interesting since the brangkas has many variation.

\section{LITERATURE REVIEW}

\subsection{Children's Anxiety after the Disaster}

Indonesia is one of disaster country. The disaster may have been passed, but its effect will remain in the victim's mind. Stressor after the disaster trauma cause mental disorder that may occur until $10-30$ years later (Pitaloka, 2007). The children usually have magical thinking that causes misinterpretation on the phenomenon they face. Even worse, they don't have verbal skill to describe the experience (the disaster). The problem of children's growth in normal population is $10 \%$ and it will increase when it is followed by other risk factors, such as disaster. Problem of stress after disaster will increase twice, while $30 \%$ of the victims face permanent emotional and health disorder for 2-3 years after the disaster. $10-20 \%$ of disaster victims will face mental disorder, such as post trauma stress disorder (PTSD), depression, panic, and anxiety (Kar et al., 2013).

Anxiety is one of common mental disorders on children. According to Diagnostic and Statistical Manual of Mental Disorders, around 9-10\% of preschool children have anxiety problem (Egger \& Angol, 2008). Mean of boys and girls is relatively similar, but girls have more tendencies to face the problem with ratio $2: 1$ until 3:1. Once a child is diagnosed having anxiety syndrome, he / she will face the similar syndrome, additional anxiety syndrome, and depression. Children with anxiety syndrome have more risks to be depressed, have concentration \& hyperactivity problem, have Oppositional Defiant Disorder (ODD), and other problems. Children are usually sensitive and they tend to face the trauma by their own different emotional response. It's also difficult for them to recover from bad experience. Thus, they need effective support for parents, teachers, and environment (National Institute of Mental Health, 2008). Problems related to children's emotion can be resolved by play therapy. Play therapy for anxiety syndrome on children has strong empirical support for children. Stressors faced by the children, such as relocation, affect the children's psychological condition. Teachers and parents complain about the change on the children's behavior after the disaster; take Merapi eruption or Earthquake in Bantul Yogyakarta or landslide in Banjarnegara Central Java as the examples. Children become more aggressive, especially boys. The boys become naughtier, more sensitive, weepy, impatient, unruly, and have more excessive attachment. The children have no interest to go to the school because the parents unable to deliver and accompany the children in the school. After the disaster, the children are still resounded by the condition when the disaster happens. When there is cloud, electricity power failure, heavy rain, thunderbolt or wind, children often cry in fear suddenly and call for their parents. Children's anxiety syndrome in disaster area is a psychological problem that may lead to permanent disorder, which disturb the growth process on children, when it's not resolved well.

\subsection{Doll Made of Unused Goods}

There are so many unused goods in our surrounding that can be used in some activities. One of the usages of this unused good is by making them become play therapy media. The usage of unused goods in therapy aims to make children aware of the problem of overflowing landfills, to introduce the 
practices of reusing and recycling as a means to help reduce the amount of waste we generate, to help children learn to sort various 'trash'items by matching them to recycling labels. (Departement of Natural Resources, 2012).

One kind of unused goods used in play therapy media making is scrap paper (from magazine, newspaper, paper bag). It can be used to make play tools for increasing the language acquisition and fine motor skill and can be used to make percussion instrument (Asmawati L., 2015). Cardboard and carton can be made as beam, building, musical instrument, doll scaffold, pattern maker, and so on. Plastic or aluminum glass, bottle, or bag can be used to make communication tools, musical instruments, and tools for measuring activity in playing water and sand. Unused goods are used in order to increase the children's creativity. Sinnamon (2012) said that: "Children will learn that most items can be recycled instead of being thrown away".

Similarly, Silamy (in Houseine and Rosouli, 2015) said that: "Creativity is the desire and talent to create a cast of all ages in all subjects and the potential environmental and socio cultural continuity is directly and closely". Play therapy media made of unused goods synergize potential environmental and socio cultural directly and closely. The children who make unique products will grow as individual with high self-esteem, independent thought, and awareness of their potential for bright future.

Play therapy using media will attract the children's interest to follow therapy process. Therapy media is tools or any kind of aids used as a message deliver during therapy in order to get the goal of therapy (Tresnawati, 2013). Doll is a visual media. Brangkas (doll made of unused good) is imitation thing in form of human body, animal, or anything, which has unique form and attractive color, made of unused goods. According to Siswanti (2012), the advantages of using doll are: a) don't need large space in its applying; b) don't require any complicated skill in its applying; c) can develop the children's imagination; d) increase the children's activeness and make happy atmosphere; e) develop children's linguistic aspect. Doll as a play media therapy has many advantages. Children usually like doll, so that the goal message can be relatively delivered. The doll made of unused good, but as attractive as other dolls, will attract the children's interest and attention. Children also can involve in playing the doll. It means that 'brangkas' can be a distraction and therapy media to express their felling. 'Brangkas' also boosts the children imagination (Gunarti, 2012).

Brangkas' media used in therapy post disaster can be the alternative way to solve the children's problems related to their psychological condition. This play therapy media can reposition the children as an individual that need other people in their life, need social interaction, and need to cooperate in a team with their peers. This doll can appear as various figures according to the delivered message. Though the doll used unused goods, it is still able to increase the children's concentration since it uses colorful stuff, colored liquid, and various attractive and imaginative forms.

\section{RESEARCH METHOD}

This research uses quasi experiment research with one group pre-posttest design. Subjects are observed before intervention is done. The population in this research is children between $3-9$ years old in disaster areas in Central Java; Wonosobo regency, Banyumas regency, and Prambanan district Klaten regency. Regional Disaster Management Board said that there are 112 children live in disaster areas and are susceptible to stressor due to disaster. The samples are 30 children by using purposive sampling technique. The subjects of this research never get the therapy previously. Data is gathered using questionnaire. The subjects' anxiety level is measured using standardized Revised Children's Manifest Anxiety Scale (RCMAS). The researchers use the materials in expert-tested play therapy using 'brangkas' module. The data is analyzed using univariate analysis to know the anxiety distribution and using Wilcoxon test as well.

\section{RESEARCH RESULT AND DISCUSSION}

The data general below describe the characteristics of research subjects based on gender, experience of disaster, and age, whereas, the specific data include anxiety level before and after the treatment using 'Brangkas'. 
Table 1. Subjects' distribution based on age

\begin{tabular}{|c|c|c|}
\hline Age & Amount & percentage \\
\hline 3-4 years old & 7 & $23 \%$ \\
\hline $5-6$ years old & 11 & $37 \%$ \\
\hline $7-8$ years old & 9 & $30 \%$ \\
\hline $8-9$ years old & 3 & $10 \%$ \\
\hline \multicolumn{2}{|l|}{ Total } & $100 \%$ \\
\hline
\end{tabular}

Based on table 1, it's found that the most subjects are in the age of $5-6$; that is 11 children $(37 \%)$.

Table 2. Subjects' anxiety level before the treatment using 'Brangkas'

\begin{tabular}{|c|c|c|}
\hline Anxiety Level & Amount & Percentage \\
\hline physiologic & 9 & $30 \%$ \\
\hline Oversensitivity & 12 & $40 \%$ \\
\hline Concentration Anxiety & 9 & $30 \%$ \\
\hline Total & 30 & $100 \%$ \\
\hline
\end{tabular}

Table 3. Subjects' distribution based on the change on RCMAS scale after the treatment using 'Brangkas' media

\begin{tabular}{|c|c|c|c|c|c|}
\hline $\begin{array}{c}\text { Anxiety } \\
\text { level }\end{array}$ & Change/decrease & \multicolumn{4}{|c|}{ Total } \\
\hline physiologi & 7 & 2 & 2 & 7 & 30 \\
c & 11 & 3 & 1 & 3 & 40 \\
$\begin{array}{c}\text { Oversensi } \\
\text { tivity }\end{array}$ & 8 & 3 & & & \\
$\begin{array}{c}\text { Conc. } \\
\text { Anxiety }\end{array}$ & & 7 & 1 & 3 & 30 \\
\hline \multicolumn{1}{|c|}{} & & 2 & & & \\
\hline & 26 & 8 & 4 & 13 & 100 \\
\hline & & 7 & & \\
\hline
\end{tabular}

Based on table 3, it's known that there are 7 subjects in physiologic anxiety level having anxiety score decrease after play therapy treatment using 'Brangkas' media. However, 2 children have the similar score in this case. After play therapy treatment using 'Brangkas' for the subjects with oversensitivity is done, it's found that 11 subjects decrease their anxiety, while 1 subject have the similar anxiety. In concentration anxiety problem, after the treatment using 'Brangkas', it's found that 8 subjects are able to decrease their anxiety, though 1 subject still have the similar anxiety. Based on Wilcoxon test, it results $(p=0,000, z=-3.296)$. It means that doll made of unused goods (Brangkas) influence the anxiety level. To sum up, 'Brangkas' decreases the children's anxiety in disaster areas.

Anxiety is an individual response to unpleasant fact and it's faced by all people in their daily life. Therapy for them, people with anxiety, should use representative media. Using this doll made of unused goods (brangkas), children can learn many things. Children will communicate more, adjust themselves to new environment, do what they can do, and recognize time, distance, and sound.

Responses of physiological anxiety are agitated, nervous, strained, worried, watchful, guilty feeling, and shy. Children with disaster effect problem often express hostility, anger, or other negative thinking by different way such as by doing irritability and aggressive action to others, doing self-withdrawal, refusing relationship with peers, refusing sibling, having attitude problem in school. Physiological anxiety is related to anxiety of uncertainty feeling and powerlessness. During anxiety period, people usually focus the attention to other people or other things, or even ignore something

Doll made of unused goods is one of media and alternative way used to help children solve their anxiety syndrome since playing is verbal symbol for children. Responses of children's physiological anxiety due to disaster can be in form of stomachache, nausea, vomit, agitation, concentration problem, and irritability (King \& Bernstein, 2014). Harrel (2013) said that therapy treated for children will be effective if it's done therapeutically and the children do it happily. Similarly, according to Madyawati (2015) play activities will be very attractive for children in disaster areas. This doll can increase the children's willingness to have positive attitude. This doll is in line with the children's growth, thus it can resolve the children's emotional and mental disorder.

Fear of disaster often haunts the children. It causes many negative responses such as become aggressive, angry, and rebellious, have verbal expression in form of saying expletive words, reject cooperation, and become dependent to certain believed people. Other emotional responses of children stress may because of separation anxiety feeling to their beloved or because of strange environment (refuge). Children's stress and anxiety are also influenced by children's personal characteristic, such as age, gender, culture, and previous disaster experience. The fact forces them to stay in refuges and separate to their social group cause anxiety for children. Different situation and condition between their home and refuge make them lost their self-control.

From this research, it's found that the treatment using doll made of unused goods (brangkas) can decrease the children's anxiety in disaster areas. It's supported by Supartini (2015) who said that playing can decrease children's anxiety level. Playing using 
therapeutic media is constituted by notion that playing is healthy activity for children, needed for children's growth, and might be able to help the children dig and express their feeling and thought, divert negative feeling and relax themselves. Playing activity using representative media should be integral part of children's psychological health service in disaster areas. Playing media are used as an effort to decrease the children's anxiety level during and after the disaster. Attractive media used in attractive playing strengthen the relationship between client (children and their parents) and therapist since therapist can build good relationship toward the children and their parents during playing activity. Playing media is an effective communication tools between therapist and client. After children are given the doll made of unused good (brangkas), they feel more relax and have willingness to interact and communicate to the therapists.

The children's happiness and serenity after the activity using brangkas evidently heal the children's psychological syndrome due to emotional disorder. 'Brangkas' can be an alternative media for children's therapist and psychologist because it's adjusted according children's need and development. 'Brangkas' media not only gives happiness for children but also helps the children express their feeling and thought of anxiety, fear, sadness, and nervousness. It will make the children become more cooperative and relax, so that they can retrieve their positive attitude and don't show behavioral disorder anymore.

\section{CONCLUSIONS}

Based on research result and analysis, it can be conclude that: 1) the doll made of unused goods was able to decrease the children's anxiety in disaster areas; 2) 7 (23\%) subjects with physiological anxiety faced anxiety decrease; 3 ) oversensitivity anxiety left one subject (3\%); 4) previously, concentration anxiety is faced by 9 subjects (30\%), but it decrease until 1 subject (1\%) who still face it; 5) based on Wilcoxon test, it is found a significant result, that is $\mathrm{p}=0,000$ and $\mathrm{z}=-3.926$. it means that brangkas is able to decrease the children's anxiety in disaster areas. Suggestions from the writers are: 1) for therapists and any related party concern on the children's life in disaster areas, it's suggested to use 'Brangkas' as one of media in psychological healing; 2) suggest the children institution around the disaster areas to develop play therapy media; 3 ) for further research on related topic, this research result can be used as reference for similar research in the future.

\section{ACKNOWLEDGEMENTS}

The writers want to say thank you for: 1) General Director on Strengthening of Research And Development, Research Technology and Higher Education Ministry; 2) coordinator of Private University Association (Kopertis) VI semarang; 3) Regional Disaster Management Board Central Java province; 4) Regional Disaster Management Board Banyumas Regency; 5) Regional Disaster Management Board Klaten Regency; and 6) instructors and therapists from Banyumas and Klaten regency.

\section{REFERENCES}

American Psychiatric Association. (2000) Diagnostic and Statistical Manual of Mental Disorders Fourth EditionText Revision, DSM-IV-TR. Arlington, VA: American Psychiatric Association.

Bernstein, D and King. (2014). Nelson Texbook of Pediatrics 18th Edition. Saunders Elsevier, Philadelphia: 1828- 1928.

Coyne, I. (2008)." Children Experience of Hospitalization". Journal of Child Health Care. Vol 10 (4) 326- 336

Departement of Natural Resources. (2012).

Egger, H. Angold,A.(2008). Common Emotional and Behavioral Disorders in Preschool Children: Presentation, Nosology, and Epidemiology. Journal Child Psychology Psychiatry 47 (3/4): 313- 317.

Folley, N. (2010). Lesion Location and Depression: Systematic Review of The Methodological Limitations in The Literature. Depression. 35: 749802.

Gunarti, dkk. (2012). Metode Pengembangan Perilaku dan Kemampuan Dasar Anak Usia Dini. Jakarta: Universitas Terbuka.

Harrel,A., Wright, A. (2013). A Journal of Practice \& Theory.

Houseini, E.A and Rosouli.E. (2015) Study Aimed to Investigate the Impact of Quality of Work Live on Employee Creativity. Journal of Social Issues \& Humanities, Volume 3, 2345- 2632.

Hurlock,E.B. (1999). Psikologi Perkembangan: Suatu Pendekatan Sepanjang Ruang Kehidupan. Edisi 5. Jakarta: Erlangga.

Kalayjian, Ani dan Poloutzian F.Raymond. (2009). Forgiveness and Reconciliation Psychological Pathway to Conflict Reconcoliation. New York: Springer. USA.

Kar et.al. (2013). Pengaruh Kecemasan Terhadap Kualitas Hidup. Universitas Sumatera Utara. Medan. 
Luluk, Asmawati. (2015). Materi Pokok Pengelolaan Kegiatan Pengembangan PAUD. Jakarta: Universitas Terbuka.

Lystad, M., (2005). Innovative Mental Health Services for Child Disaster Victims. Children Today, 14 (1): 1317.

Madyawati, L. (2015) Pengembangan Kegiatan Bermain Berbasis Kecerdasan Jamak Sebagai Implementasi Sekolah Ramah Anak di Daerah Bencana Jawa Tengah. Laporan Penelitian (Hiba DIKTI) (Tidak diterbitkan).

National Institute of Mental Health. (2010) Depresion and College Students. NIMH, 1-8.

Pitaloka, A. Menelusuri Kecemasan pada Remaja. http://www.epsikologi.com/sosial/080107.htm (diakses 17 Juni 2016).

Shoaakazemi, M., Javid,M.M. (2012). The Effect of Group Play Therapy on Reduction of Separation Anxiety Disorder in Primitive School Children. Social and Behavioral Sciences, 69: 95- 103.

Siswanti, Rosi. (2014). Pengaruh Tayangan Kekerasan Terhadap Perilaku Menyimpang pada Anak (Studi Kasus Anak di RT 12 Kec. Taman, Sidoarjo). Tidak diterbitkan.

Speier, W. (2007). Is proton beam therapy cost effective in the treatment of Adenocarainoma. Journal of Clinical Oncology 25(4), 3603- 3608.

Stetler, Sinnamon. (2002). Clinical Deppression and Inflammatory Risk Markers for Coronary Heart Disease. The Americal Journal of Cardiology Vol.90, 12, (1279- 1283).

Supartini, Yupi. (2008). Buku Ajar Konsep Dasar Keperawatan Anak. Jakarta: EGC.

Trisnawati, S.K. (2013). Faktor Resiko Kejadian Depresi Pada Anak di Kec. Cengkareng Jakarta Barat. Jurnal Ilmiah Kesehatan, 6- 11.

Wright. (2005). Personality and Behavior. England: McGraw- Hill International. 